\title{
Effectiveness of Local Wisdom-Based Leadership Training to Improve the Competence of Middle School Principals
}

\author{
Yohanes Harsoyo ${ }^{1} \&$ Wigati Retno Astuti ${ }^{2} \&$ Caecilia Wahyu Estining Rahayu ${ }^{3}$
}

\begin{abstract}
${ }^{1,2 \& 3}$ Sanata Dharma University, Mrican, Catur Tunggal, Depok, Sleman, Yogyakarta, Indonesia Correspondence: Yohanes Harsoyo, Sanata Dharma University, Mrican, Catur Tunggal, Depok, Sleman, Yogyakarta, Indonesia.

Email: yohanes.harsoyo@gmail.com
\end{abstract}

doi: 10.23918/ijsses.v6i2p41

\begin{abstract}
This study is intended to determine whether there are differences in the competency of principals both in the aspects of knowledge and attitudes before and after the training of secondary school principals. Principal competency training is carried out by incorporating leadership values based on local wisdom. The number of samples of this study were 30 high school principals from Yogyakarta Special Province, Central Java Province, and East Java Province. Data collection was carried out by questionnaire and interview. Data analysis techniques were carried out quantitatively and qualitatively. Based on the results of data analysis, it can be concluded that there are differences in the competencies of secondary school principals in the aspects of knowledge and attitudes before and after training.
\end{abstract}

Keywords: Principal Competency, Leadership, Values of Local Wisdom

\section{Introduction}

A school principal is a leader of one institution. Its position is very strategic to make a decision whether the school can achieve its educational goals. Griffith (2004), Mustamin and Yasin (2012) state that a principal is the key in school success. The principal has complex roles and tasks which are generally not be accomplished easily. In general, every principal has a role as a school manager. However, the principals sometimes have to be a supervisor, an entrepreneur, a school and community liaison, and many others. The work environment which is dynamic, both within and outside the school, and unpredictable changes brings uncertainty in many ways. In this case, the principal is the first person who should be able to make clarity in making decisions about what the teachers and staff should do (Oreg \& Berson, 2011). Therefore, every principal must have certain competencies which are needed in order to influence and involve people in the school to achieve the goals which have been decided (Tizard, 2001). In Indonesia, the National Education Ministry formulates five dimensions of principals' competencies, namely personality, management, entrepreneurship, supervision, social (Ministry of National Education, 2007).

The competencies above are not just basic knowledge and skills, but it refers to the actual abilities of someone to knowledge and skills in real-life practice at the school (Kin, Kareem, Nordin, \& Bing, 2017). A principal even needs to experience local cultural values while keeping focusing on fulfilling national needs and global demands (Slamet, 2014). His main tasks are to select and choose appropriate leadership values that are needed by the school and to transmit those values to both teachers and students. Moreover, a school principal is expected to be able to think globally and act by paying attention to the values of local wisdom. Some of the research gave empirical evidence that local wisdom values were effective to be 
applied in the school's learning context. Leksono, Rustaman, \& Redjeki (2015) reported that the application of the local wisdom based conversation biology courses has increased biodiversity literacy (investigating, developing the process skills, developing the concept mastery, and acting by appreciating biodiversity) and having formed conservation characters. Wulandari \& Mundilarto (2016) reported that Physics 'active learning tools of local wisdom based on tournament learning have effectively increased students' concept mastery and character values. Furthermore, Sumardjoko (2018) reported that the learning model of local wisdom based on civic education was effective to improve character scores, national identity, and learning mastery. Those pieces of research showed that the implementation of local wisdom values was effective to obtain learning goals. Therefore, principals were supposed to be able to implement local wisdom values through their leadership considering local wisdom values have advantages to obtain the education goals.

In Javanese culture contexts, Javanese conserve local wisdom not only in their minds, yet also in their senses. They don't only have ordinary experiences, yet they also have some acts. In Java, local wisdom tends to be physically and spiritually central to struggle to obtain salvation of life (Wagiran, 2011). It is no doubt that the values of culture and local wisdom have been made in Yogyakarta and Mataraman people are poly, adaptable, acceptable, hardworking, forward thinking, and competitive. Based on history, local wisdom has supported the existence of a nation. Japan, South Korea, and German, for example, shows that their national values are contributed to their country's advancement (Wagiran, 2011). Thus, learning about values of local wisdom and act those values is very important to gain the excellence of leaders, including the principals. To better deliver better results, it is necessary to develop competency of school principals and adapt the local values continuously in the form of education and training.

This research is intended to test the effectiveness of the principal's leadership training. The principal's leadership training is designed with regard to the values of local wisdom, especially Javanese. The school leadership model based on the values of local wisdom is seen as able to move teachers to always ask themselves about the practices that have been implemented in the classroom so that teachers are encouraged to always improve their decisions and learning processes in class. The process of continuous change is expected to have an impact on students, teachers, and other interested parties.

\section{Literature Review}

Local wisdom is part of culture. Local wisdom is an element of traditional culture that is rooted in human and community life related to human resources, cultural resources, economy, security and law. Local wisdom can be seen as a tradition associated with agricultural activities, animal husbandry, building houses, and others (Geertz, 1973). Various analyzes show that the values of local wisdom have a contribution to the progress of a nation. Internationally, the following examples can be illustrated. The progress achieved by Japan is inseparable from the inculcation of the nation's unique values, the 'Bushido' work ethic. This work ethic is one of the solid foundations for the development of Japanese modernization. Extraordinary progress was also achieved by South Korea. Through the 'Semaul Undong' movement, which saw the glory and values of the past, became the basis for moving forward and competing with other nations in the global era. Likewise the progress achieved by Germany with the Protestant work ethic (Wagiran, 2011). 
Indonesian society is known as a plural nation (Buwono X, 2007). Indonesia's diversity is not only because it consists of around 17,500 islands connected by the ocean, but also because of its rich ethnicity, ethnicity, language, culture, religion, and customs. Because of this diversity, Indonesia is often said to be a multicultural country. The uniqueness and specificity of certain cultures is the potential that can be processed to penetrate today's global culture. Therefore, the richness of Indonesian culture needs to be explored and introduced and developed by every Indonesian man. The role of education through school becomes important to develop this.

Leadership is always related to values. As a leader, a person is expected to act based on personal values and clear professional values (Bush \& Glover, 2014). A study by Day, Harris, \& Hadfield (2001) report that the principal will carry out his function with a set of personal values and educational values that will represent his moral goals for the school. This shows that there are dominant values agreed upon and determined by the government and other values that support the principal to run his leadership in the school (Bush, 2007). These values are local values that have long been embedded in a society, which live and be lived in the community through a long process even throughout the cultural history of a nation. These local values in practice color the leadership of the school principal. Local wisdom is part of culture (Geertz, 1973). Wisdom of local values is considered appropriate to be applied in a place with certain cultures and at the same time become an identity that distinguishes it from other places. Local wisdom is an element of traditional culture that is rooted in human and community life related to human resources, cultural resources, economy, security and law (Geertz, 1973).

There are three popular Javanese local wisdom-based leadership values. These values are (1) Asta Brata, (2) Sistem Among, and (3) Sastra Gendhing. First, Asta Brata. The most popular teachings of local values according to respondents are Asta Brata. The term Asta Brata means eight behaviors that must be possessed by a leader, namely 'Laku Hambeging Surya' (leaders are able to provide energy encouragement to subordinates slowly, which will unwittingly guide subordinates to carry out common goals); 'Laku Hambeging Samirana' (leaders have a meticulous nature when they go down to pay attention or supervise the performance of all subordinates); 'Laku Hambeging Candra' (leader has a jovial nature that is able to please the subordinates); 'Laku Hambeging Dahana' (leader has a strict nature in governing, especially when giving punishment to subordinates who make mistakes), 'Laku Hambeging Kisma' (the leader has a generous and fair attitude towards all his followers), 'Laku Hambeging Angkasa' (the leader has the nature of being able to add scientific value to subordinates); 'Laku Hambeging Samodra' (leaders have an open attitude and are able to accommodate the aspirations of their subordinates); and 'Laku Hambeging Kartika ' (leaders have the confidence to uphold the principles they believe in). This leadership teaching was widely accepted by school principals through wayang kulit performances, especially in the 'Lakon Makutha Rama'. 'Lakon Makutha Rama' is not the only source of this teaching, other sources describing Asta Brata are 'Serat Manawa Dharmacastra', 'Serat Rama', 'Serat Nitisruti', and 'Serat Pustakaraja Purwa' (As'ad, Anggoro, \& Virdanianty, 2011). Even though there are many sources, the source of the shadow puppet show is the main source for school principals to know the teachings of Asta Brata; Second, the 'Sistem Among'. The second most popular teaching according to the headmaster is the teaching expressed by Ki Hadjar Dewantara which reads: "ing ngarsa sung tuladha, ing madya mangun karsa, tut wuri handayani" or often called 'Sistem Among' (Dewantara, 1930). Ki Hadjar Dewantara considers that the leadership position is dynamic, can be in the front, in the middle and can also be in the back depending on the 
situation. Principals consider that the values in the 'Sistem Among' are always relevant in education. Within this 'Sistem Among' there are democratic values, where the principal may not act arbitrarily but instead encourages participation from all school members who are often perceived as lacking. Principals consider that the teachings about the among systems are suitable to be integrated with training materials related to personality competencies, social competencies, supervisory competencies, and managerial competencies (Wangid, 2009); Third, 'Sastra Gendhing'. The third order of Javanese values deemed relevant to the competency of the principal is the principles of Sultan Agung Hanyakrakusuma's leadership (1613-1645) expressed through 'Sastra Gendhing'. This fiber contains teachings that contain seven moral rules. The seven rules are a form of Javanese leadership which is considered ideal. This great work is an accumulation of the moral teachings of the leadership of the king of Mataram.

\section{Methodology \\ 3.1 Participants}

The number of principals as the participants of this research are 30 high school principals, both junior and senior high school, originating from the Yogyakarta Special Province, Central Java Province, and East Java Province. The selected schools are located in the area which is culturally affected by Mataraman culture. Mataraman culture refers to an area which is influenced by the culture of Islamic Mataram, including the culture of Surakarta and Yogyakarta, that is a fraction of Islamic Mataram.

\subsection{Procedure}

The researcher used quantitative and qualitative analysis techniques. Quantitative analysis techniques are carried out by comparing the principal's responses before and after the principal's training. Data were analyzed based on paired-samples $t$ test. While qualitative analysis techniques are complementary to quantitative data analysis techniques. The steps of qualitative analysis technique done were data condensation (selecting, simplifying, abstracting, transforming the data that approached the whole part from written field notes, interview transcripts, documents and any other empirical materials), data display (organizing, combining information for possible conclusions and actions), and conclusions (drawing conclusions and verifying) (Miles, Huberman, \& Saldana, 2014).

\subsection{Instrument}

Data were gathered by collecting questionnaires (open-ended and closed-ended questions). The questionnaire itself is about school competencies according to Education Ministerial Regulation No.13 / 2007 on Competency Standards of School / Madrasah (Islamic Schools) Principals which consist of social competency, personality competency, supervision competency, managerial competency, and entrepreneurial competency. Also, the questionnaire is about the values of local wisdom that are popular among the principals and the Javanese leader figures. 


\section{Results \& Discussion}

\subsection{Results}

Researchers distributed 30 closed questionnaires to respondents to find out the principals' competences, namely managerial competencies, entrepreneurial competencies, supervision competencies, personality competencies, and social competencies, before and after training. The research result is presented in Table 1 .

Table 1. Description of principals' competencies before and after the training

\begin{tabular}{lrrrrr}
\hline $\begin{array}{l}\text { Principals' } \\
\text { Competency }\end{array}$ & $\begin{array}{c}\text { Theoretical } \\
\text { range }\end{array}$ & $\begin{array}{c}\text { Actual } \\
\text { range }\end{array}$ & Mean & $\begin{array}{r}\text { Standard } \\
\text { deviation }\end{array}$ & $\begin{array}{r}\text { Std. Error } \\
\text { Mean }\end{array}$ \\
\hline $\begin{array}{l}\text { Knowledge aspect } \\
\text { Before training }\end{array}$ & $0-20$ & $8-11$ & 9.80 & 1.215 & .222 \\
After training & $0-20$ & $14-18$ & 16.13 & 1.008 & .184 \\
Attitude aspect & & & & & \\
Before training & $15-75$ & $55-59$ & 55.27 & 8.461 & 1.545 \\
After training & $15-75$ & $63-71$ & 66.20 & 9.711 & 1.773 \\
\hline
\end{tabular}

The description of principals' competencies which are related to managerial competency (aspects of knowledge) before the principal's training was lacking, whereas after the principal's training was good. While managerial competency (knowledge aspects) before training the principal was adequate, while after the training the principal was good.

Statistical test results show that between the principals' competencies in the aspect of knowledge, there are significant differences before and after training (.000). Meanwhile, the principal's competence in the aspect of attitude showed that before and after the training there was a significant difference (.000) (Table 2).

Table 2. Paired samples test

\begin{tabular}{|c|c|c|c|c|c|c|c|c|c|}
\hline & \multicolumn{5}{|c|}{ Paired Differences } & \multirow[b]{3}{*}{$\mathrm{t}$} & \multirow[b]{3}{*}{$\mathrm{df}$} & \multirow{3}{*}{$\begin{array}{l}\text { Sig. (2- } \\
\text { tailed) }\end{array}$} \\
\hline & & \multirow[b]{2}{*}{ Mean } & \multirow{2}{*}{$\begin{array}{c}\text { Std. } \\
\text { Deviation }\end{array}$} & \multirow{2}{*}{$\begin{array}{l}\text { Std. Error } \\
\text { Mean }\end{array}$} & \multicolumn{2}{|c|}{$\begin{array}{l}\text { 95\% Confidence } \\
\text { Interval of the } \\
\text { Difference }\end{array}$} & & & \\
\hline & & & & & Lower & Upper & & & \\
\hline $\begin{array}{l}\text { Pair } \\
1\end{array}$ & $\begin{array}{l}\text { Knowledg } \\
\text { e aspect }\end{array}$ & -6.333 & 1.422 & .260 & -6.864 & -5.802 & $\begin{array}{r}- \\
24.389\end{array}$ & 29 & .000 \\
\hline $\begin{array}{l}\text { Pair } \\
1\end{array}$ & $\begin{array}{l}\text { Attitude } \\
\text { aspect }\end{array}$ & 10.933 & 4.093 & .747 & -12.462 & -9.405 & $14.630^{-}$ & 29 & .000 \\
\hline
\end{tabular}




\subsection{Discussion}

The results of this study indicate that the training of principals based on local wisdom increases principals' competencies in aspects of knowledge and attitudes. In the aspect of knowledge, this training increased knowledge and skills in thinking in managing schools. While in this aspect the attitude of the training makes the principal have a certain attitude in accordance with the position and desires and needs of the school.

Managerial competence: Through this training, school principals are able to improve managerial competencies, for instance principals' competence to manage the resources by planning, organizing, directing, and monitoring to obtain school's goals effectively was considered good. This finding illustrated that the principals became more able to implement appropriate strategies to empower educational staff, to give them opportunities to elevate their professions, and to encourage them to engage in some school program activities effectively and efficiently. However, the principal has a strategic role in determining school strategies, plans, and management practices to develop academic culture in schools (Tian, Risku, \& Collin, 2015). To develop good management strategies, they require both technical and non-technical competence. Principal competencies will affect the quality of decisions and define actions in school education practice. Through the time, good actions and practices will affect teachers' beliefs through the transformation of school culture (Macneil, Prater, \& Busch, 2009). Therefore, principals' managerial competencies as seen in the research above needs to develop more and be in line with the local values in society.

Entrepreneurial competence: Through this training, principals are able to increase principals' entrepreneurial competencies, for instance nature, characters, and characteristics of individuals and also have a strong willingness to realize and develop creative and innovative ideas into valuable activities, were categorized good. This finding pictured out that the principals possessed entrepreneurial skills, especially on creative thinking and innovative acts. The finding of the study reveals that there are two indicators of entrepreneurial competence that are considered difficult to do, namely: (1) having entrepreneurial instincts in managing schools 'activities as a source of students' learning; and (2) creating innovations that were useful for the schools' development. The principal is a teacher who has many experiences as a teacher. The entrepreneurial spirit is not much developed in their careers as a teacher. Therefore, the biggest challenge for the principals is to create useful innovations for schools. They feel overwhelmed enough to accommodate changes which come from government, especially those which are related to curriculum and administration.

Supervison competence: Through this training, principals are able to improve the principals 'supervision competences, that is the principals' efforts in leading teachers and staff to improve teaching, including human resources development in schools, developing and updating educational goals, teaching materials, teaching methods, and teaching evaluations, were categorized good. This finding pictured out that the principals have adequate supervision competences to manage the educational resources at school in order to obtain the education goal. The finding of this research revealed that the principals found it difficult to follow up academic supervision results of teachers for improving their professionalism by academically supervising them using appropriate supervision approaches and techniques. The interviews revealed that: firstly, the principals feel that they have a lot of agendas to do, so they find it difficult to manage their time 
to do the supervision. Generally, time for supervision has been arranged and agreed by the principals and the teachers, but the principals cannot always make it due to their hectic schedule that makes them have to rearrange the time or cancel the supervision. In contrast, supervision on other aspects tend to the physical aspects that support the learning activity, such as fund management, employees, buildings, equipment and other facilities; secondly, changes in the old curriculum to the new curriculum demand changes in the learning process. Teachers might have attended trainings on how they implemented a new curriculum, but it is not enough. This condition causes the teachers to be ignorant about the implementation and they tend to ask the principals, while the principals feel incompetent enough to explain the answers. It often makes the principals feel unconfident in doing the supervision so the supervision tends to prioritize administrative technical aspects rather than academic aspects. In fact, the aspect which should be concerned is the quality of learning process in the school. Administrative documents, notes, and teacher reports are also important because it is used to obtain the overview of the learners' quality in the learning process; thirdly, the conditions which the facilities are owned by the institutions are limited, such as textbooks, props, laboratories, and other facilities. This also becomes the main reason why teachers find it difficult to change their teaching methods according to the curriculum.

Social competence: Through this training, principals are able to improve the principals' managerial competences, that were the skills in attitude and cooperating with the social environment at school, were categorized good. This condition depicted the principals who already had skills and good relationships with the teachers, staffs, students, and social environment at school. These competencies need to be maintained. Based on the interviews, the principals said that they were trying to be warm with teachers, staffs, students, and also to be friendly with the environment outside, such as the social community, educational self-help organizations, and surround communities. Relationships between the outsiders are generally in the form of inter-institutional cooperation. On many occasions, the collaboration between outsiders and schools is done because of the initiatives of the outsiders, such as universities, businesses, and communities. The cooperation with universities is done in the form of the Field Experience Practice program. The cooperation with business world is done in the form of cooperation in corporate study and sponsorship for school activities. The cooperation with communities is done by participating in the communities' events or activities. Principals generally do not have the authority to reject any cooperation with outsiders. On the other hand, they are lack of initiative on how to optimize the cooperation so it can improve the quality of their schools.

The principals' ability to manage the relationships with outsiders, understanding the thoughts, feelings, perspectives, wider description; they are able to be flexible in facing the change (Saxe, 2011). This attitude can predict the further attitude that can encourage reformation and positive performance in the school. Social competence is the antecedent of the transformational leadership in schools (Cerado \& Abdullah, 2015). Goleman, Boyatzis and McKee (2002) state that the individuals who have social awareness do not only need to understand, but also need to empathize with the others 'perspectives, understand the wider descriptions due to decision-making and organizations' business. This skill is crucial in encouraging resonance as a leader who has an awareness of what others think and feel will make them easy to take decisions in particular situations. However, the ability to manage relationships needs a combination of skills such as motivating others in the same vision of the organization and persuading the others through various tactics in order to support the development of skills, abilities, and new performance. Conflicts in 
relationships in social tasks are inevitable. The ability to deal with conflicts effectively is very important in relationships with people at school to encourage the organization to be better.

Personality competence: Through this training, the principal is able to increase the principals' personality competence, that was a personal characteristic; for instance, the nature and attitude of a person related to one's behavior was categorized good. This condition depicted the principals had good traits, attitudes, and behaviors and were able to be role models for teachers, staffs, students, and school environments. However, the finding of this study shows that personality competence is a competence which is considered difficult by the principals. These are the personality competencies which are perceived as difficult consecutively: open, noble, integrity, strong desire, self-control, and having talent and interest. The interviews with the principals indicate that as school leaders, they have to be a good role model for teachers, staffs, and students. A principal has to believe that whoever becomes a leader has a good role model for others. The model itself is not only about in words, but also in action which can be seen and felt by others in schools. For them, being a role model in the school is considered a moral burden. They no longer feel free as teachers. Among the various attitudes, being open is the most difficult attitude they do because they have a feeling of "ugly pakewuh" which means that if something is wrong and say it is wrong, then it can hurt the others' hearts and it can lead to disharmony among the principal, teachers, and staff at the school.

The finding explains why some of the characteristics of leaders and situations are related to the followers' perception of a leader as an ethical leader (Bandura, 1986, Browne-Ferrigno \& Muth, 2004). In social learning theory, leaders are ethical leaders for their followers. Leaders must be attractive and credible role models. Social learning theory also helps explain about why and how ethical leaders can influence their followers. Followers will pay attention and imitate the attitude, value, and behavior of an attractive and credible model (Bandura, 1986). Most individuals reflect what is outside their selves to other individuals for ethical guidance (Trevino, 1986; Halbusia, Theseen, \& Ramayah, 2017). The ethical leader can be a source of guidance because of their attractiveness and credibility as role models. Power and status are two model characteristics that increase their attractiveness (Bandura, 1986), thus it makes the followers pay attention to the behavior of the models. Most leaders have authority because they have a position of status relative to their followers. However, attractiveness takes an important role more than power and status. Credibility also improves the effectiveness of the model. Ethical leaders can be trusted because they can be trusted and they are responsible in doing what they say. Therefore, if the leaders do not obey what they say, then there is no reason for others to do so (Bandura, 1986). Moreover, the finding of the research also shows that the principals have a burden to be a spiritual leader. When someone is in a spiritual leadership position, it means having to be able to embody spiritual values such as integrity, honesty, and humbleness, become a person who can be trusted, relied, and admired. Spiritual leadership is also shown through behavior, either in individual reflective practice or in ethical, compassionate, and respecting others (Reave, 2005).

\section{Conclusion}

Based on the results of the data analysis, it can be concluded that the training of principals based on local wisdom increases the competency of principals in the aspects of knowledge and attitudes. However, they 
have not yet understood the leadership values based on Asta Brata and Literary Gending. In relation to the findings of this study, it is necessary to train more prospective principals and principals to improve the principal's competence. Therefore, it is necessary to improve the training for the principal. Future principal training needs to be evaluated which things need improvement. In addition, training can be done by emphasizing the aspects of the application rather than the theoretical aspects. Training also needs to involve relevant institutions, training materials need to be made more varied, training models such as on the job training or apprenticeships to principals who are categorized as excellent should be done, and others. Future research needs to be done by identifying factors related to the principal's competence, as well as the impact of the principal's competence on school performance.

\section{References}

As'ad, M., Anggoro, W.J., \& Virdanianty, M. (2011). An exploratory study of Javanese leadership constructs: Asta Brata, Jurnal Psikologi, 38(2), 228 - 239. doi: 10.22146/jpsi.7655.

Bandura, A. (1986). Social foundations of thought and action: A social cognitive theory. Englewood Cliffs, NJ: Prentice Hall.

Boyatsis, R.E. (1982). The competent manager: A model of effective performance. New York: Willey.

Browne-Ferrigno, T., \& Muth, R. (2004). Leadership mentoring in clinical practice: Role socialization, professional development, and capacity building. Educational Administration Quarterly, 40(4), 468-494. doi: 10.1177/0013161X04267113.

Bush, T. (2007). Educational leadership and management: Theory, policy, and practice. South African Journal of Education, 27(3), 391-406. Retrieved from https://www.ajol.info/index.php/saje/article/viewFile/25107/4321.

Bush, T., \& Glover, D. (2014). School leadership models: What do we know? School Leadership \& Management, 34(5), 553-571. doi: 10.1080/13632434.2014.928680.

Buwono X, S.H. (2007). Knit back to our Indonesia. Jakarta: Gramedia.

Cerado, E.C., \& Abdullah, S.N. (2015). Emotional intelligence and social competence: Antecedents of school administrators' transformational leadership qualities. Journal of US-China Public Administration, 12(3), 180-184. doi: 10.17265/15486591/ 2015.03.002.

Day, C., Harris, A., \& Hadfield, M. (2001). Challenging the orthodoxy of effective school leadership. International Journal of Leadership in Education, 4(1): 39-56. doi: 10.1080/13603120010010615.

Dewantara, K.H. (1930). Teaching the national establishment and nature of student parks. Speech at the Taman Siswa General Meeting in Malang 2 February 1930.

Education Ministerial Regulation No.13/2007 on Competency Standards of School/Madrasah, Jakarta.

Geertz, C. (1973). The interpretation of cultures. New York: Basic Books, Inc.

Goleman, D., Boyatzis, R.E, \& McKee, A. (1995). Primary leadership: Realizing the power of emotional intellegence. Boston: Harvard Business School Publishing.

Griffith, J. (2004). Relation of principal transformational leadership to school staff job satisfaction, staff turnover, and school performance. Journal of Educational Administration, 42(3), 333-356. doi: 10.1108/09578230410534667.

Halbusia, H.A., Tehseen, S., \& Ramayah, T.C. (2017). The impact of organizational justice on the ethical leadership under the moderating influence of perceived support: A conceptual study. Malaysian Journal of Business and Economics, 4(1), 46-64. Retrieved from https://www.researchgate.net/publication/322097653.

Kin, T.M., Kareem, O.A., Nordin, M.S., \& Bing, K.W. (2017). Principal change leadership competencies and teacher attitudes toward change: The mediating effects of teacher change 
beliefs. International Journal of Leadership in Education, 21(4), 1-20. doi: 10.1080/13603124.2016.1272719.

Leksono, S.M., Rustaman, N., \& Redjeki, S. (2015). The effect of the application of conservation biology courses based on local wisdom on the ability of biodiversity literacy of prospective teacher students. Cakrawala Pendidikan, 34(1), 89-96. doi: 10.21831/cp.v1i1.4179.

Macneil, A. J., Prater, D. J., \& Busch, S. (2009). The effects of school culture and climate on student achievement. International Journal of Leadership in Education, 12, 73-84. doi: 10.1080/13603120701576241.

Miles, M.B., Huberman, A.M., \& Saldana, J. (2014). Qualitative data analysis: A methods sourcebook. Washington DC: Sage Publications.

Ministry of National Education. (2007). School entrepreneurship (Training material for fostering the competencies of prospective principals/principals). Jakarta.

Ministry of Education and Culture. (2013). The principal's supervision competency still needs to be improved. Retrieved from http://www.kemdikbud.go.id/ kemdikbud/berita/1430.

Mustamin, \& Yasin, M.A. (2012). The competence of school principals: What kind of need competence for school success? Journal of Education and Learning, 6(1), 33-42. doi: 10.11591/edulearn.v6i1.188.

Oreg, S., \& Berson, Y. (2011). Leadership and employees' reactions to change: The role of leaders' personal attributes and transformational leadership style. Personnel Psychology, 64(3), 627659. doi: 10.1111/j.1744-6570.2011.01221.x.

Reave, L. (2005). Spiritual values and practices related to leadership effectiveness. The Leadership Quarterly, 16(2005), 655-687. doi: 10.1016/j.leaqua.2005.07.003.

Saxe, D. (2011). The relationship between transformational leadership and the emotional and social competence of the school leader. Dissertations. Paper 63. Retrieved from http://ecommons.luc.edu/luc_diss/63.

Slamet, PH. (2014). The politics of Indonesian education in the 21st century. Cakrawala Pendidikan, 33(3), 324-337. doi: 10.21831/cp.v3i3.2377.

Sumardjoko, B. (2018). Model of civic education learning based on the local wisdom for revitalizing values of Pancasila. Cakrawala Pendidikan, 37(2), 201-211. doi: 10.21831/cp.v37i2.18037.

Tian, M., Risku, M., \& Collin, K. (2015). A meta-analysis of distributed leadership from 2002 to 2013. Theory development, empirical evidence, and future research focus. Educational Management, Administration, and Leadership, 44(1), 146-164. doi: $10.1177 / 1741143214558576$.

Tizard, J. (2001). Seamless change. Management, 48(7), 62-65.

Trevino, L.K. (1986). Ethical decision making in organizations: A person-situation interactionist model. Academy of Management Review, 11(3), 601-617. doi: 10.2307/258313.

Wangid, M.N. (2009). Current among systems: Study of educational concepts and practices. Jurnal Kependidikan, 39(2), 129-140. doi: 10.21831/jk.v39i2.209.

Wagiran. (2011). Development of local wisdom education models in supporting the vision of development of the Yogyakarta Special Region Province of 2010. Jurnal Penelitian dan Pengembangan, III(3), 85-100. Retrieved from http://staffnew.uny.ac.id/upload/ 132297916/penelitian/Pendidikan+kearifan+lokal.pdf.

Wulandari, W.T., \& Mundilarto. (2016). Development of active physics learning device type learning tournament based on local wisdom. Cakrawala Pendidikan, 35(3), 365-377. doi: 10.21831/cp.v35i3.10433. 